J. Great Lakes Res. 34:228-234

Internat. Assoc. Great Lakes Res., 2008

\title{
Sources and Sinks of Escherichia coli in Benthic and Pelagic Fish
}

\author{
Dennis L. Hansen'1, John J. Clark'1, Satoshi Ishii², \\ Michael J. Sadowsky ${ }^{2,3}$, and Randall E. Hicks ${ }^{1, *}$ \\ ${ }^{1}$ Department of Biology \\ University of Minnesota Duluth \\ 207 Swenson Science Building \\ 1035 Kirby Drive \\ Duluth, Minnesota 55812-3004 \\ ${ }^{2}$ Department of Soil, Water, and Climate \\ ${ }^{3}$ BioTechnology Institute \\ University of Minnesota \\ 439 Borlaug Hall, 1991 Upper Buford Circle \\ St. Paul, Minnesota 55108
}

\begin{abstract}
Escherichia coli and fecal coliform bacteria were isolated from five benthic and four pelagic fish species to determine their role in the fecal contamination of recreational waters. All fish were collected during fall 2006 from Southworth Marsh in the Duluth-Superior Harbor, a public beach that is commonly posted to minimize water contact due to high E. coli levels. Although fecal coliform bacteria were isolated from each fish species, they were only isolated from $66 \%$ and $72 \%$ of the individual benthic and pelagic fish, respectively. While $42 \%$ of the fecal coliforms from benthic fish were E. coli, only $4 \%$ of these bacteria from pelagic fish were E. coli. Cluster analysis showed different fish species harbored identical strains of E. coli and some fish contained multiple E. coli strains. The potential source for $65 \%$ of the E. coli isolates obtained from fish were identified by using the HFERP DNA fingerprinting method and libraries of E. coli DNA fingerprints from warm-blooded animals and environmental isolates collected in the area. The E. coli strains whose source could be identified were most similar to strains isolated from sediments, Canada geese, mallard ducks, and wastewater. None of the fish E. coli had DNA fingerprints matching those from any water or beach sand isolates. Although our results demonstrate that benthic fish contain E. coli, it may be more appropriate to consider these fish as a vector of E. coli from other sources, rather than a new source of $\mathrm{E}$. coli contamination in aquatic environments.
\end{abstract}

INDEX WORDS: Fecal coliforms, E. coli, benthic fish, pelagic fish, sediment, microbial source tracking.

\section{INTRODUCTION}

The presence of Escherichia coli is currently used as an indicator of recent fecal contamination in recreational waters. There are many possible sources of E. coli in the environment, including waterfowl (Alderisio and DeLuca 1999, Ishii et al. 2007, Jones et al. 1978, Levesque et al. 2000, Standridge et al. 1979), wildlife (all animals except waterfowl) (Ishii et al. 2007, Johnson et al. 2004, Vogel et al. 2007), algae and periphyton (Ishii et al. 2006b, Ksoll et al. 2007, Whitman et al. 2003),

\footnotetext{
${ }^{*}$ Corresponding author. E-mail: rhicks@d.umn.edu
}

soils and sediments (Byappanahalli et al. 2006, Ishii et al. 2006a, Ishii et al. 2007), and treated wastewater effluent (Ishii et al. 2007, USEPA 1986). Wild fish, however, are relatively understudied and often an overlooked potential source of $E$. coli. There have been several studies on the presence of fecal coliforms (FC) in farm-reared fish because of concern about the health of fish consumers. Molinari et al. (2003) reported that bacteria in the genera Aeromonas, Burkholderia, Chromobacterium, Citrobacter, Escherichia, Flavimonae, and Plesiomonas are present in farm-raised tilapia. Del Rio-Rodriguez et al. (1997) used E. 
coli-laden feed to infect rainbow trout ( $O n$ corhynchus mykiss) intestines and Al-Harbi (2003) detected $E$. coli in farm raised tilapia intestines and correlated them with pigeon droppings.

In contrast, there have been relatively few studies about the presence of fecal coliforms and E. coli in wild fish. Geldreich and Clarke (1966) showed that fecal coliforms and Streptococcus faecalis could be found in fish intestines. They speculated that fecal coliforms are not part of the permanent microflora in fish, but their presence is caused by polluted water and is influenced by feeding habits. Guzman et al. (2004) found two fish species that harbored $E$. coli from a river contaminated by sewage effluent. Their work also supported the view that fish obtain $E$. coli from the environment. None of the aforementioned studies attempted to trace the sources of $E$. coli in these fish using any technique. Microbial source tracking techniques (Santo Domingo and Sadowsky 2007), which have been used to identify the sources of environmental $E$. coli, can also be used to identify the sources of $E$. coli in fish. Knowing these sources would allow us to better understand the role, if any, that fish play in microbial contamination of aquatic habitats.

To trace the sources of $E$. coli isolated from wild fish, we used the horizontal fluorophore enhanced rep-PCR (HFERP) DNA fingerprinting technique, as described by Johnson et al. (2004) and Ishii et al. (2007). The HFERP method compares E. coli DNA fingerprints of interest to a library of fingerprints from known sources, and has been successfully used to identify the probable source of unknown environmental E. coli strains (Byappanahalli et al. 2006, Ishii et al. 2007, Ksoll et al. 2007). The objectives of our study were to [i] determine if fecal material from fish in the Duluth-Superior Harbor contained fecal coliforms and E. coli, and [ii] determine if $E$. coli found in fish fecal material are primarily from animal or environmental sources.

\section{METHODS}

\section{Site Description}

Southworth Marsh (46 $44^{\prime} 26.370^{\prime \prime} \mathrm{N}, 92^{\circ} 03^{\prime}$ $42.804^{\prime \prime} \mathrm{W}$ ) is a public beach in the Duluth-Superior Harbor in Duluth, MN that is monitored for E. coli contamination by the Minnesota Pollution Control Agency (MPCA, http://www.mnbeaches.org/ beaches/lksuperior/B036.shtml). The site is a popular recreation area for sailing, kayaking, and rowing, and is frequently visited by mallard ducks (Anas platyrhynchos) and Canada geese (Branta
Canadensis). Signs not recommending water contact are frequently posted at the Southworth Marsh beach by the MPCA in the summer and fall due to high $E$. coli levels.

\section{Fish Collection and $E$. coli Verification}

Fish were collected at Southworth Marsh with fyke nets from August through October 2006. The benthic species collected were the common carp (Cyprinus carpio; $\mathrm{n}=6$ ), white sucker (Catostomus commersonii; $\mathrm{n}=6$ ), brown bullhead (Ameiurus nebulosus; $\mathrm{n}=9$ ), ruffe (Gymnocephalus cernuus; $\mathrm{n}=3$ ), and round goby (Neogobius melanostomus; $\mathrm{n}=8)$. The pelagic species were white perch (Morone Americana; $\mathrm{n}=10)$, yellow perch (Perca flavescens; $\mathrm{n}=3$ ), pumpkinseed (Lepomis gibbosus; $\mathrm{n}=6$ ), and rock bass (Ambloplites rupestris; $\mathrm{n}=6$ ).

Fecal coliform (FC) bacteria were isolated from fecal material of these five benthic and four pelagic species (Table 1). After collection, the fish were transported in harbor water to the lab where their intestines were aseptically removed. Fecal material was extracted from intestines and plated onto $\mathrm{mFC}$ agar (Difco, Detroit, MI) to isolate fecal coliform bacteria. The isolation and verification of $E$. coli were completed as described by Ishii et al. (2006a), with minor changes. After overnight incubation at $44.5^{\circ} \mathrm{C}$, colonies that were dark blue on $\mathrm{mFC}$ agar were transferred to MacConkey Agar (Difco). Pink and red isolates on MacConkey agar were tested on CHROMagar ECC (CHROMagar Microbiology, Paris, France). Bacterial colonies that were white or blue on CHROMagar ECC were verified to be E. coli as described by Ishii et al. (2006a). Isolates testing positive as E. coli were stored in a $50 \%$ glycerol solution in CryoTube ${ }^{\mathrm{TM}}$ vials (Nunc, Roskilde, Denmark) at $-80^{\circ} \mathrm{C}$ until DNA fingerprints were obtained by using the HFERP DNA fingerprinting method (Johnson et al. 2004).

\section{HFERP Analysis and Host Library}

Fish isolates were initially compared to a host library of HFERP DNA fingerprints of E. coli from animals and wastewater collected from northeastern Minnesota. The host E. coli library consisted of 955 unique DNA fingerprints from 8 sources, including herring gulls (Larus argentatus; 4 fingerprints), beaver (Castor Canadensis; 10), deer (Odocoileus virginianus; 52), ducks (72), common terns (Sterna hirundo; 91), Canada geese (139), ring-billed gulls 
TABLE 1. Pelagic and benthic fish sampled from Southworth Marsh in 2006. This table shows the percentages of fish species harboring fecal coliforms, E. coli, and the relative abundance of E. coli in each fish species.

\begin{tabular}{l|ccccc}
\hline \hline & Number & $\begin{array}{c}\text { Fish with } \\
\text { Fecal } \\
\text { Coliforms } \\
(\%)\end{array}$ & $\begin{array}{c}\text { Fecal } \\
\text { Coliforms } \\
\text { Tested } \\
\text { (number) }\end{array}$ & $\begin{array}{c}\text { Fish with } \\
\text { E. coli } \\
(\%)\end{array}$ & $\begin{array}{c}\text { E. coli } \\
\text { isolates } \\
\text { (number) }\end{array}$ \\
\hline Yellow Perch & 3 & 100 & 27 & 0 & 0 \\
Pumpkinseed & 6 & 67 & 20 & 0 & 0 \\
White Perch & 10 & 50 & 6 & 10 & 1 \\
Rock Bass & 6 & 100 & 30 & 17 & 2 \\
\hline Total & 25 & 72 & 83 & 8 & 3 \\
\hline
\end{tabular}

\begin{tabular}{l|rrrrr} 
Benthic Fish & \multicolumn{7}{l}{} \\
\hline Brown Bullhead & 9 & 56 & 26 & 22 & 24 \\
Ruffe & 3 & 67 & 1 & 33 & 1 \\
Round Goby & 8 & 38 & 3 & 25 & 2 \\
White Sucker & 6 & 100 & 18 & 0 & 0 \\
Common Carp & 6 & 83 & 19 & 17 & 1 \\
\hline Total & 32 & 66 & 67 & 19 & 28 \\
\hline
\end{tabular}

(Larus delawarensis; 247), and treated wastewater (340). E. coli strains were isolated from the Western Lake Superior Sanitary District's (WLSSD) sewage treatment facility, which is $4.5 \mathrm{~km}$ from Southworth Marsh and discharges effluent into the Duluth-Superior Harbor. Fingerprints from fish E. coli that could not be matched to an animal host were then compared to a library of 1,163 DNA fingerprints from environmental $E$. coli isolates. This environmental E. coli library contains strains from water, beach sand, and sediments, collected from Southworth Marsh during 2005 and 2006.

Cluster analysis, and bootstrap identification of the fish $E$. coli fingerprints were assessed by using BioNumerics software (Applied Maths, SintMartens-Latem, Belgium) as described by Ishii et al. (2006a) and Johnson et al. (2004). A dendrogram was created using the unweighted pair group method with arithmetic means (UPGMA) and Pearson's product-moment correlation coefficient (Ishii et al. 2006a, 2007; Johnson et al. 2004). Only fingerprints that matched a source in the host or environmental libraries with a $\mathrm{p} \geq 0.90$ were considered a match (Byappanahalli et al. 2006, Ishii et al. 2007).

\section{RESULTS}

Culturable fecal coliforms were found in each fish species, but only $66 \%$ of the benthic fish and $72 \%$ of the pelagic fish contained fecal coliform bacteria (Table 1). The percentage of benthic fish harboring fecal coliforms was not statistically different $(p>0.1)$ than the percentage of pelagic fish containing fecal coliforms. On average, only $19 \%$ of the benthic fish examined contained E. coli, which was not different from the pelagic fish species (average of $8 \%$; $p>0.1$ ). However, the percentage of fecal coliforms isolated from benthic fish that were verified as E. coli $(42 \%)$ was 10 times greater than for the pelagic fish species examined $(4 \% ; \mathrm{p}<0.10)$.

We considered $E$. coli isolates to be clones (i.e., identical strains) if the similarity of their HFERP DNA fingerprints was $\geq 92 \%$ (Ishii et al. 2006a, Ishii et al. 2007). E. coli strains isolated from all fish clustered into 12 strain groups using this criterion (Fig. 1). ID bootstrap analysis identified the probable origin of $E$. coli in nine of these strain groups, and $65 \%$ of the $E$. coli isolated from all fish $(\mathrm{n}=31)$ likely originated from animal or environmental sources. Almost all of these E. coli were obtained from benthic fish (18 of 20 strains), primarily from brown bullheads.

Overall, E. coli strains from all benthic and pelagic fish combined, whose source could be identified, were most similar to $E$. coli found in beach sediments (8 isolates), Canada geese (6 isolates), mallard ducks ( 3 isolates), and wastewater ( 3 isolates). Most of the E. coli strains identified to be from beach sediments were found in brown bull- 


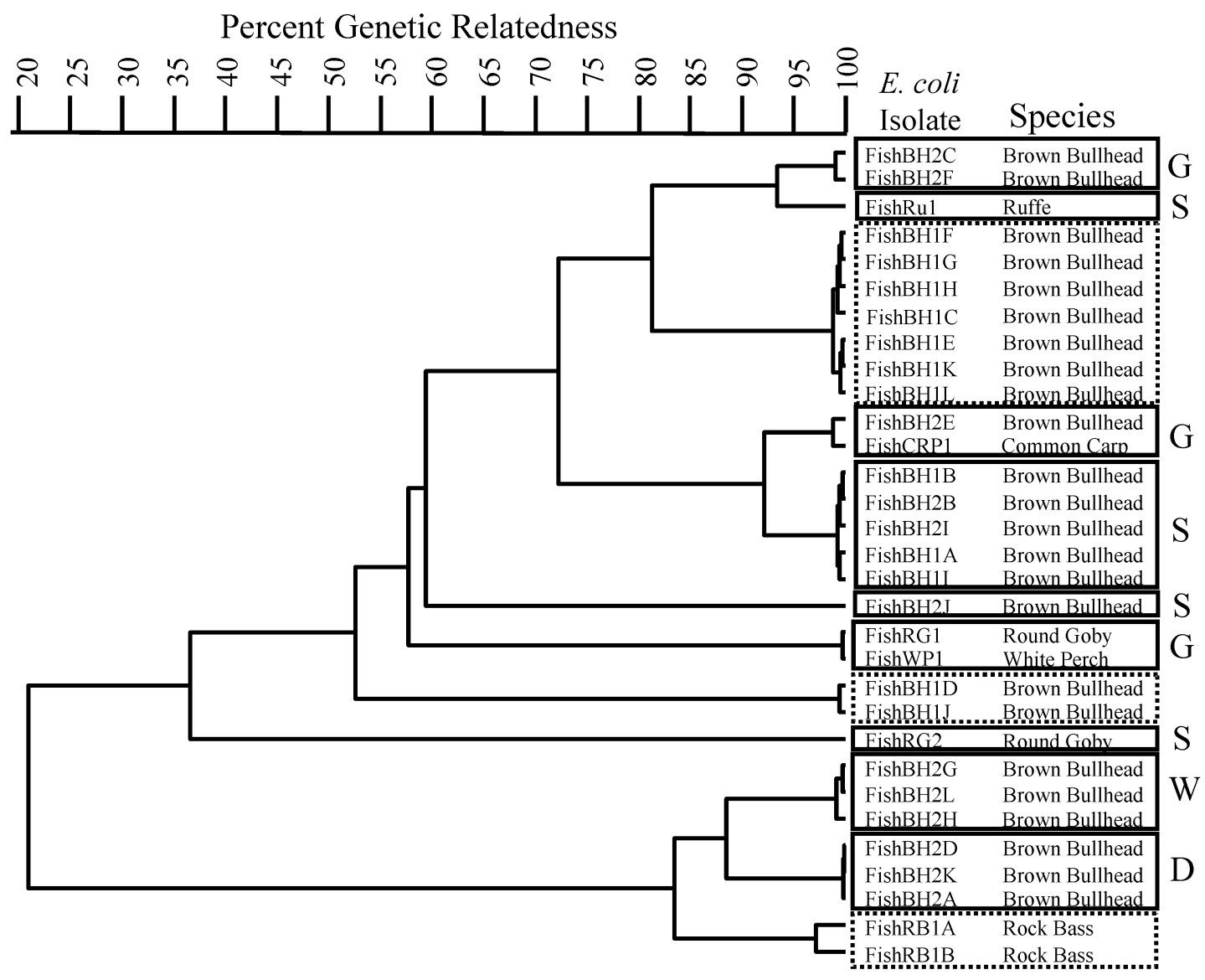

FIG. 1. Dendrogram showing the genetic similarity of $\mathbf{E}$. coli isolated from different fish and the probable source of these $\mathbf{E}$. coli. The $\mathbf{E}$. coli isolates in solid-line boxes at the right were from the same source. These sources are denoted to the right of each box: $S=$ sediment, $G=$ Canada geese, $D=$ mallard ducks, and $W=$ wastewater $\mathbf{E}$. coli. Boxes with dotted-lines indicate groups of fish E. coli whose source could not be identified using the HFERP method and the animal and environmental source libraries. The scale bar represents percent similarity of the HFERP DNA fingerprints of each strain.

heads, although sediment E. coli strains were also found in two other benthic fish species, ruffe and the round goby (Fig. 1). The E. coli strains from Canada geese were found in brown bullheads, common carp, round goby, and white perch. A round goby and white perch fish shared an E. coli strain originating from Canada geese. Brown bullheads were the only fish that contained $E$. coli from mallard ducks and wastewater. The two $E$. coli strains isolated from the pelagic rock bass were identical, but the source of this strain group could not be identified using our animal and environmental source DNA fingerprint libraries.

Most of the E. coli strains that could be identified were obtained from brown bullhead, but this was not surprising considering that most $E$. coli were isolated from this species (Table 1). The brown bullheads harbored a variety of E. coli strains (Fig. 1 ), and isolates from one of these fish were found in three different E. coli strain groups. An animal or environmental source for two of these strain groups could not be identified, but the third strain group was most similar to $E$. coli isolated from beach sediments. This $E$. coli strain was also found in another brown bullhead that also harbored $E$. coli strains from five other strain groups, which were most similar to Canada geese ( 2 clusters), mallard ducks (1 cluster), and wastewater (1 cluster). 


\section{DISCUSSION}

The presence of fecal coliform bacteria in the intestinal tracts of fish that inhabit polluted waters is well documented (Al-Harbi 2003, Del Rio-Rodriguez et al. 1997, Stanistaw and Tucholski 2000, Geldreich and Clarke 1966, Guzman et al. 2004, and Trust 1975). Fecal coliforms in fish are influenced by fish feeding habits, and fish can harbor fecal coliforms up to 14 days after being exposed to contaminated water (Geldreich and Clarke 1966). In our study, fecal coliforms were found in the fecal materials of every fish species examined, but not every fish. This inconsistency supports Geldreich and Clarke's (1966) view that fish may not harbor stable populations of fecal coliforms, but rather acquire allochthonous microorganisms in conjunction with feeding activity.

Geldreich and Clarke (1966) also found that benthic fish species harbored more fecal coliforms than pelagic species. Our results are consistent with their observation. Although the percentages of benthic and pelagic fish species harboring fecal coliforms or $E$. coli were not significantly different, the percentage of fecal coliforms verified to be $E$. coli in benthic fish was 10 times larger than the percentage in pelagic fish species. It might be expected that benthic fish would harbor more $E$. coli than pelagic fish because $E$. coli are less abundant in water than in sediments (Desmerais et al. 2002, Ishii et al. 2007, LaLiberte and Grimes 1982, Obiri-Danso and Jones 2000), where benthic species often feed. The digestive tracts of benthic fish are probably inoculated with fecal coliforms from the sedimentary organic material they consume (Del Rio-Rodriguez et al. 1997, Trust 1975). We recognize that if brown bullheads had not been sampled, then the percentage of fecal coliforms verified to be E. coli in benthic fish would be more similar to the pelagic fish species examined. Brown bullheads may not be representative of all benthic fish species. Clearly, additional studies are needed to more thoroughly document differences in the numbers of fecal coliforms and E. coli found in benthic and pelagic fish species.

An animal or environmental source could be identified for $65 \%$ of all E. coli isolated from fish fecal materials used in this study. The remaining $35 \%$ of the E. coli may come from sources not represented in our animal or environmental sources libraries, or possibly some E. coli strains may have become naturalized to fish. Unfortunately, our results cannot be used to determine which of these cases may be true for the unidentified strain groups. If any of the unidentified strains could be repeatedly isolated from the fecal materials of the same fish species over a longer period than that used in our study, then it may be possible to determine if the unidentified strains were naturalized to fish intestinal tracts using the criteria defined by Ishii et al. (2006a), Ishii et al. (2007), and Ksoll et al. (2007).

Of the E. coli isolates from fish fecal materials whose source could be identified, $60 \%$ were from various animal hosts and the remaining $40 \%$ likely originated from sediments. Even though most of the $E$. coli were isolated from benthic fish species, it is interesting that none of them matched environmental E. coli strains obtained from water or beach sand at Southworth Marsh. Whitman et al. (2004) showed that exposure to sunlight can inactivate E. coli in water. Sediments, where benthic fish often feed, contain higher levels of E. coli than water (Obiri-Danso and Jones 2000, Ishii et al. 2007), and sediment materials probably provide bacteria some protection against light-induced inactivation. Considering these facts, it appears less likely that pelagic fish will ingest or be inoculated by as many E. coli as benthic fish.

Canada geese, mallard ducks, and wastewater were the next most common sources of $E$. coli found in benthic fish. Canada geese and mallard ducks regularly forage and sleep at Southworth Marsh, and approximately 45 million gallons of treated wastewater are discharged into the DuluthSuperior Harbor each day (http://www.ci.superior. wi.us/index.asp?nid=83, www.wlssd.com/waste water_treatmentprocess.php). E. coli from waterfowl and treated wastewater have been found to settle onto sediments (Ishii et al. 2007), where they may be consumed by benthic fish. However, other studies have shown that $E$. coli can survive for long periods and some strains may become naturalized to soils and periphyton (Gordon et al. 2002, Whitman et al. 2003, Ishii et al. 2006a, Ksoll et al. 2007). Naturalized strains of E. coli could also persist in fish. It is clear from our data, however, that the fecal material from at least one benthic fish species (e.g., brown bullheads) was not dominated by a single $E$. coli strain, but rather contained many strains from multiple animal and environmental sources. Certainly, additional studies having more $E$. coli isolates for each fish species than we obtained could help confirm this finding. Still, it is probably more appropriate to consider the fish species in this study as vectors of $E$. coli from other 
sources rather than a new source of E. coli contamination in waterways, considering the small percentage of fish in each species that contained $E$. coli and the multiple sources of $E$. coli found in brown bullheads.

\section{ACKNOWLEDGMENTS}

We thank the United States Environmental Protection Agency, Mid-Continent Ecology Division of the National Health and Environmental Research Laboratory, in Duluth, MN for loaning us their nets. We also thank Jenna Bergin, Jason Kish, John Gralewski, William Rusk, and Ryan Oster for providing technical assistance in the field and the lab.

This work was supported by the University of Minnesota Undergraduate Research Opportunities Program (to J. J. C.) and by a grant from the Minnesota Sea Grant College Program, NOAA Office of Sea Grant, United States Department of Commerce, under grant no. NA03-OAR4170048 (to R.E.H. and M.J.S.). The U.S. Government is authorized to reproduce and distribute reprints for government purposes, not withstanding any copyright notation that may appear hereon. This paper is journal reprint No. JR. 544 of the Minnesota Sea Grant College Program.

\section{REFERENCES}

Alderisio, K.A., and DeLuca, N. 1999. Seasonal Enumeration of Fecal Coliform Bacteria from the Feces of Ring-Billed Gulls (Larus delawarensis) and Canada Geese (Branta canadensis). Appl. Environ. Microbiol. 65:655628-5630.

Al-Harbi, A.H. 2003. Faecal coliforms in pond water, sediments, and hybrid tilapia Oreochromis niloticus $\mathrm{x}$ Oreochromis aureus in Saudi Arabia. Aquaculture Res. 34:517-524.

Byappanahalli, M.N., Whitman, R.L., Shively, D.A., Sadowsky, M.J. and Ishii, S. 2006. Population structure, persistence, and seasonality of autochthonous Escherichia coli in temperate, coastal forest soil from a great lakes watershed. Environ. Microbiol. 8:504-513.

Del Rio-Rodriguez, R.E., Inglis, V., and Millar, S.D. 1997. Survival of Escherichia coli in the intestine of fish. Aquaculture Res. 28:257-264.

Desmarais, T.R., Solo-Gabriele, H.M., and Palmer, C. J. 2002. Influence of soil on fecal indicator organisms in a tidally influenced subtropical environment. Appl. Environ. Microbiol. 68:1165-1172.

Geldreich, E.E., and Clarke, N.A. 1966. Bacterial pollution indicators in the intestinal tract of freshwater fish. Appl. Microbiol. 14:429-437.

Gordon, D.M., Bauer, S., and Johnson, J.R. 2002. The genetic structure of Escherichia coli populations in primary and secondary habitats. Microbiology 148:1513-1522.

Guzman, M.C., Bistoni, M.A., Tamagnini, L.M., and Gonzalez, R.D. 2004. Recovery of Escherichia coli in fresh water fish, Jenynsia multidentata and Bryconamericus iheringi. Water Research 38: 2368-2374.

Ishii, S., Ksoll, W.B., Hicks, R.E., and Sadowsky, M.J. 2006a. Presence and growth of naturalized Escherichia coli in temperate soils from Lake Superior watersheds. Appl. Environ. Microbiol. 72:612-621.

, Yan, T., Shively, D.A., Byappanahalli, M. N., Whitman, R.L., and Sadowsky, M.J. 2006b. Cladophora (Chlorophyta) spp. harbor human bacterial pathogens in nearshore water of Lake Michigan. Appl. Environ. Microbiol. 72:4545-4553.

, Hansen, D.L., Hicks, R.E., and Sadowsky, M.J. 2007. Beach sand and sediments are temporal sinks and sources of Escherichia coli in Lake Superior. Environ. Sci. Technol. 41:2203-2209.

Johnson, L.K., Brown, M.B., Carruthers, E.A., Ferguson, J.A., Dombek, P.E., and Sadowsky, M.J. 2004. Sample size, library composition, and genotypic diversity among natural populations of Escherichia coli from different animals influence accuracy of determining sources of fecal pollution. Appl. Environ. Microbiol. 70:4478-4485.

Jones, F., Smith, P., and Watson, D.C. 1978. Pollution of a water supply catchment by breeding gulls and the potential of environmental health implications. $J$. Institution of Water Engineers and Scientists 32:469-482.

Ksoll, W.B., Ishii, S. Sadowsky, M.J. and Hicks, R.E. 2007. Presence and sources of fecal coliform bacteria in epilithic periphyton communities of Lake Superior. Appl. Environ. Microbiol. 73:3771-3778.

LaLiberte, P., and Grimes, D.J. 1982. Survival of Escherichia coli in lake bottom sediment. Appl. Environ. Microbiol. 43:623-628.

Levesque, B., Brousseau, P., Bernier, F., Dewailly, E., and Joly, J. 2000. Study of the content of ring-billed gull droppings in relation to recreational water quality. Water Res. 34:1089-1096.

Molinari, L.M., Scoaris, D.de O., Pedroso, R.B., Bittencourt, N.de L.R., Nakamura, C.V., Ueda-Nakamura, T., Filho, B.A.de A., and Filho, B.P.D. 2003. Bacterial microflora in the gastrointestinal tract of Nile tilapia, Oreochochromis niloticus, cultured in a semiintensive system. Acta Scientiarum Biol. Sci. 25:267-271.

Obiri-Danso, K., and Jones, K., 2000. Intertidal sediments as reservoirs for hippurate negative Campylobacters, Salmonellae, and faecal indicators in three EU recognised bathing waters in northwest England. Water Res. 34:519-527. 
Santo Domingo, J.W., and Sadowsky, M.J. 2007. Microbial Source Tracking. Washington D.C.: USA. American Society for Microbiology.

Standridge, J.H., Delfino, J.J., Kleppe, L.B., and Butler, R. 1979. Effect of waterfowl (Anas platyrhynchos) on indicator bacteria populations in a recreational lake in Madison, Wisconsin. Appl. Environ. Microbiol. 38:547-550.

Stanistaw, N., and Tucholski, S. 2000. Reduction of bacterial contamination of common carp under various rearing condition. Arch. Polish Fisheries 8:63-74.

Trust, T.J. 1975. Facultative anaerobic bacteria in the digestive tract of chum salmon (Oncorhynchus keta) maintained in fresh water under defined culture conditions. Appl. Microbiol. 29:663-668.

Vogel, J.R., Stoeckel, D.M., Lamendella, R., Zelt, R.B., Santo Domingo, J.W., Walker, S.R., and Oerther, D.B. 2007. Identifying fecal sources in a selected catchment reach using multiple source-tracking tools. J. Environ. Qual. 36:718-729.

USEPA. 1986. Ambient water quality criteria for bacteria. United States Environmental Protection Agency. Washington DC. EPA440/5-84-002.

Whitman, R.L., Shively, D.A., Pawlik, H., Nevers, M.B., and Byappanahalli, M.N. 2003. Occurrence of Escherichia coli and Enterococci in Cladophora (Chlorophyta) in nearshore water and beach sand of Lake Michigan. Appl. Environ. Microbiol. 69: 4714-4719.

, Nevers, M.B., Korinek, F.C., and Byappanahalli, M.N. 2004. Solar and temporal effects on Escherichia coli concentration at a Lake Michigan swimming beach. Appl. Environ. Microbiol. 70:4276-4285.

Submitted: 17 July 2007

Accepted: 23 November 2007

Editorial handling: William C. Sonzogni 